\title{
POTENSI KEMOPREVENTIF EKSTRAK ETANOLIK KULIT JERUK KEPROK (Citrus reticulata) PADA KARSINOGENESIS SEL HEPAR TIKUS GALUR SPRAGUE DAWLEYTERINDUKSI DMBA
}

\section{CHEMOPREVENTIF POTENCY OF ETHANOLIC EXTRACT OF Citrus reticulata ON DMBA INDUCED RAT LIVER CELL CARCINOGENESIS}

\author{
Edy Meiyanto*, Diah Ayu Putri K.W, Perdana Adhi N, Andita Pra Darma, Muthi Ikawati \\ Cancer Chemoprevention Research Center \\ Fakultas Farmasi, Universitas Gadjah Mada, Yogyakarta \\ meiyan_e@ugm.ac.id
}

\begin{abstract}
ABSTRAK
Salah satu titik tangkap strategi penemuan agen kemopreventif kanker khususnya kanker hepar adalah melalui penghambatan proliferasi dan penekanan ekspresi onkogen c-Myc. Tangeretin, nobiletin, dan hesperidin adalah beberapa senyawa aktif dari kulit jeruk keprok (Citrus reticulate) dilaporkan memiliki efek antiproliferatif pada berbagai sel kanker secara in vitro. Hasil penelitian ini dapat bermanfaat untuk mengetahui efek ekstrak etanolik kulit C. reticulata terhadap proliferasi dan penekanan ekspresi c-Myc pada sel hepar tikus betina galur Sprague Dawley berumur 40 hari terinduksi 7,12 Dimetilbenz[a]antrasen (DMBA). Tikus dikelompokan menjadi lima kelompok: (a) DMBA, tikus diinduksi DMBA secara peroral (p.o.), dengan dosis $20 \mathrm{mg} / \mathrm{kgBB}$ dalam minyak jagung, sebanyak 10 kali selama lima minggu(b) kontrol pelarut CMC-Na, (c) kontrol ekstrak dosis $1500 \mathrm{mg} / \mathrm{KgBB}$, (d) DMBA+ekstrak $750 \mathrm{mg} / \mathrm{kgBB}$, dan (e) DMBA+ekstrak $1500 \mathrm{mg} / \mathrm{kgBB}$. Ekstrak dilarutkan dengan CMC-Na 0,5\% dan diberikan setiap hari, dimulai minggu kelima setelah pemberian DMBA. Tikus dikorbankan saat awal minggu kesepuluh setelah pemberian DMBA. Organ hepar diisolasi dan diawetkan dengan buffer formalin untuk analisis proliferasi dan imunohistokimia c-Myc. Analisis antiproliferasi dilakukan dengan metode AgNOR dan hasil menunjukan bahwa ekstrak etanolik kulit C. reticulata dosis $750 \mathrm{mg} / \mathrm{KgBB}$ memiliki potensi tinggi dalam menghambat proliferasi dan menekan ekspresi onkogen c-Myc. Hasil ini menunjukkan bahwa ekstrak etnolik kulit Citrus reticulata dapat menghambat proliferasi pada sel hepar tikus akibat pemberian DMBA melalui efek antiproliferasi dan penekanan ekspresi c-Myc.
\end{abstract}

Kata kunci: Citrus reticulata, antiproliferatif, DMBA, AgNOR, c-Myc.

\section{ABSTRACT}

One of the strategies in the discovery of the cancer chemoprevention agent especially the liver cancer is inhibition of proliferation and suppression of the expression of c-Myc oncogene. Tangeretin, nobeletin and hesperidin are some active compounds from tangerine (Citrus reticulate) peel that has been reported their anti-proliferative effect on various cancer cells in vitro. The study can be useful for determining the effects of ethanolic extract of $\mathrm{C}$. reticulate peel on prolifetaion and suppression of c-Myc expression in the liver cells of strains of Sprague Dawley female rat induced 7,12-dimethylbenz[a]anthracene (DMBA). Rats aged 40 days divided into 5 groups: (a) DMBA, $D M B A$-induced rat at a dose of $20 \mathrm{mg} / \mathrm{KgBW}$ in corn oil given 10 times in 5 weeks per oral, (b) control of the CMC-Na solvent, (c) control of the extract at a dose of $1500 \mathrm{mg} / \mathrm{KgBW}$, (d) DMBA with the extract at a dose of $750 \mathrm{mg} / \mathrm{KgBW}$ and $D M B A$ with the extract at a dose of $1500 \mathrm{mg} / \mathrm{KgBW}$. The extract that dissolved in CMC-Na 0.5\% administered daily, started in the fifth week after DMBA was given and at the beginning of the tenth week, the rats were sacrificed. Liver was isolated and preserved using buffered formalin for proliferation and immuno-histochemical analysis of c-Myc. The analysis was conducted by AgNOR method. The results showed that ethanolic extract of C. reticulate peel at a dose of $750 \mathrm{mg} / \mathrm{KgBW}$ has higher potency to inhibite proliferation of MDBA-induced liver cells and to suppress the expression of $c-M y c$ oncogene than other dose level. This result indicated that the ethanolic extract of $\mathrm{C}$. reticulata peel can inhibit proliferation cell in rat liver induced by DMBA by antiproliferation effects and suppression of c-Myc expression.

Keyword: Citrus reticulata, antiproliferatif, DMBA, AgNOR, c-Myc. 


\section{PENDAHULUAN}

Penemuan ekstrak etanolik kulit jeruk keprok (C. reticulata) sebagai agen kemopreventif menarik untuk dikaji. Tanaman jeruk banyak mengandung senyawa flavonoid diantaranya hesperidin, naringin dan flavonoid polimetoksi seperti tangeretin dan noblitein (Nogata et al., 2006). Senyawa flavonoid telah banyak diteliti manfaatnya untuk peningkatan kesehatan dan pencegahan penyakit kanker (Moriguchi et al., 2003). Dengan demikian kulit jeruk keprok dapat digunakan sebagai agen kemopreventif pada sel kanker hepar.

Proses perkembangan sel kanker terdiri dari 4 tahap, yaitu inisiasi, promosi, progresif dan metastasis, hal tersebut dapat terjadi karena adanya paparan zat karsinogenik seperti DMBA. DMBA merupakan senyawa karsinogen yang dapat membentuk metabolit reaktif dan menyebabkan DNA adduct pada sel hepar (Izzotti et al., 1999). DNA adduct akan memacu terjadinya mutasi genetik dan abnormalitas gen. Selanjutnya dapat menyebabkan terjadinya perubahan fisiologi seluler. Overekspresi onkogen N-ras dan c-Myc oleh senyawa karsinogen merupakan abnormalitas genetik yang sering terjadi pada kanker hepar (Kawajiri, 1993). Aktivasi melalui enzim tersebut dapat dihambat oleh senyawasenyawa flavonoid seperti flavone, hidroksiflavon dan galangin (Zhai et al., 1998). Oleh karena itu, senyawa flavonoid diperkirakan dapat menghambat overekspresi $\mathrm{N}$-ras dan c-Myc sehingga tingkat proliferasi sel dapat diturunkan.

Penelitian mengenai kandungan flavonoid dalam kulit jeruk keprok menunjukkan kemajuan yang positif sebagai sumber bahan penghambat pertumbuhan sel kanker. Suatu hasil penelitian menyatakan bahwa ekstrak kulit jeruk keprok mempunyai efek antiproliferatif dan dapat menginduksi apoptosis pada sel kanker lambung manusia (Kim et al., 2005). Hasil tersebut menunjukkan bahwa di dalam kulit jeruk keprok terdapat senyawa flavonoid yang berkhasiat dalam pencegahan penyakit kanker.

Penelitian ini bertujuan membuktikan khasiat kulit jeruk keprok sebagai agen kemopreventif yang berperan dalam pencegahan penyakit kanker melalui uji efeknya terhadap penghambatan proliferasi dan penekanan ekspresi c-Myc. Hasil penelitian ini dapat dijadikan landasan mengenai penggunaan kulit jeruk keprok sebagai alternatif pencegahan penyakit kanker hepar.

\section{METODOLOGI PENELITIAN \\ Bahan Tanaman dan Preparasi Ekstrak}

Jeruk keprok (C. reticulata) diperoleh pada bulan Maret tahun 2008 dari Kali Soro, Tawangmangu, Jawa Tengah dan telah dideterminasi di Laboratorium Farmakognosi Bagian Biologi Farmasi Fakultas Farmasi UGM.
Sebanyak 494 gram serbuk dimaserasi dengan etanol 96\%. Fraksi etanol yang diperoleh dipekatkan dengan rotary vaccum evaporator hingga diperoleh ekstrak kental.

\section{Hewan Uji}

Hewan uji yang digunakan adalah tikus (Rattus norvegicus) betina galur Sprague Dawley yang berumur 40 hari dengan berat badan 70-92 gram yang diperoleh dari Unit Pengembangan Hewan Percobaan, Universitas Gadjah Mada.

\section{Bahan Kimia}

7,12-dimetilbenz[a]antrazena/DMBA

(Sigma Chem. CO, St. Louis, MO) untuk induksi kanker, corn oil sebagai pelarut DMBA, aquadest (Asia Lab), CMC-Na, reagen AgNOR sebagai pewarna pengecatan histopatologi, etanol 96\% (Merck, Darmstadt), buffer formalin $10 \%$ (Asia Lab, Yogyakarta) sebagai Iarutan fiksasi organ, paraffin, minyak imersi.

\section{Pemeriksaan Kandungan Flavonoid}

Pemeriksaan kandungan flavonoid menggunakan kromatografi lapis tipis. Ekstrak yang telah diperoleh dilarutkan dalam metanol p.a. kemudian ditotolkan pada gase diam silika gel 60-F254 (Merck, Darmstadt). Identifikasi flavonoid dengan fase gerak campuran etil asetat-metanol-air $\quad(100: 13,5: 10)$. Flavonoid dideteksi pada sinar tampak, UV 254, dan UV 366 dengan pereaksi semprot sitroborat.

\section{Uji Karsinogenesis}

Desain penelitian ini merupakan modifikasi dari Tasminatun tahun 2005. Hewan uji dibagi menjadi 5 kelompok, masing-masing terdiri dari 6 ekor tikus. Sebelum digunakan, tikus diadaptasikan selama 3 hari dan hanya mendapat pakan dan minum secukupnya. Kelompok A, yaitu kelompok perlakuan DMBA, diinduksi DMBA dalam corn oil dengan dosis $20 \mathrm{mg} / \mathrm{kgBB}$ p.o. sebanyak 10 kali selama satu bulan. Kelompok B, yaitu kelompok kontrol pelarut CMC-Na dan kelompok $\mathrm{C}$ adalah kelompok kontrol ekstrak dosis $1500 \mathrm{mg} / \mathrm{kgBB}$. Kelompok $D$ dan $E$, yaitu kelompok DMBA+ekstrak (750 dan 1500 mg/kgBB), diberi ekstrak etanolik kulit $C$. reticulata yang disuspensikan kedalam CMC-Na $0,5 \%$ setiap hari selama 1 minggu (dimulai minggu kelima setelah pemberian DMBA). Setelah pemberian DMBA yang terakhir, semua tikus diberi pakan hingga akhir pengamatan. Memasuki minggu ke-9, tikus diberi perlakuan ekstrak selama 1minggu, selanjutnya dilakukan nekropsi. Organ hepar diisolasi dan diawetkan dengan buffer formalin untuk analisis proliferasi.

\section{Pengamatan Proliferasi Sel dengan AgNOR} (Argyrophillic Nucleolar Organizer Regions)

Preparat histologi diimersikan dalam buffer sodium sitrat $(\mathrm{pH} 6,0)$, diinkubasi di 
dalam autoclave pada suhu $120^{\circ} \mathrm{C}$ (tekanan 1,1-1,2 bar) selama 20 menit, didinginkan sampai suhu $37^{\circ} \mathrm{C}$, kemudian diimersikan ke dalam larutan pengecatan perak yang terdiri dari 1 bagian volume gelatin $2 \%$ dalam asam formiat $1 \%$ dan 2 bagian larutan perak nitrat $25 \%$ dalam suhu $37^{\circ} \mathrm{C}$, selama 13 menit (Derenzini et al., 2003). Pengamatan jaringan dilakukan dengan mikroskop cahaya (Olympus, Japan).

\section{Analisis Data}

Pengamatan proliferasi sel dengan mengkuantifikasi terhadap titik-titik AgNOR dengan cara mAgNOR, yaitu dengan perhitungan jumlah seluruh titik hitam pada minimal 100 sel kemudian dirata-rata dengan cara membagi jumlah seluruh titik hitam dengan jumlah sel yang diamati (Derenzini et al., 2000). Analisis data menggunakan analisis statistik dengan metode one-way ANOVA dengan tes Tukey taraf kepercayaan 95\% $(\mathrm{P}<0,05)$. Ekspresi c-Myc diamati secara kualitatif dengan melihat adanya warna coklat pada sitoplasma.

\section{HASIL \\ Ekstraksi dan Pemeriksaan Kandungan Flavonoid}

Sebanyak 494 gram serbuk kering diekstraksi, didapatkan 1 kilogram ekstrak kental sehingga diperoleh rendemen sebesar $2,15 \%$. Reaksi flavonoid dengan sitroborat menghasilkan warna kuning pada sinar tampak (Schneider, 1985). Deteksi flavonoid dalam ekstrak mununjukkan hasil yang positif.

Tabel 1-Identifikasi Flavonoid dideteksi dengan sitroborat

\begin{tabular}{ccccc}
\hline No & hRf & $\begin{array}{c}\text { Sinar } \\
\text { tampak }\end{array}$ & UV 254 & UV 365 \\
\hline 1 & 72 & $\begin{array}{c}\text { Kuning } \\
\text { lemah }\end{array}$ & Pemadaman & $\begin{array}{c}\text { Fluoresensi } \\
\text { biru-ungu }\end{array}$ \\
\hline
\end{tabular}

Keterangan: hasil elusi ekstrak etanolik kulit jeruk keprok dengan cara Kromatografi Lapis Tipis menggunakan fase diam silika 60 F 254 dan fase gerak etil-asetat:metanol:air $(100: 13,5: 10)$

\section{Pengamatan Proliferasi Sel Hepar dengan Teknik Pewarnaan AgNOR}

Metode ini memperkirakan pembelahan sel dengan mengkuantifikasi protein NORs (Nucleolar Organiser Regions) yang mengindikasikan aktivitas proliferasi kultur sel atau sebuah tumor (Derenzini et al, 2003). Gambaran preparat AgNOR organ hepar menunjukkan bahwa jumlah black dot kelompok DMBA lebih tinggi dibandingkan dengan jumlah kelompok tanpa perlakuan (Gambar 4a dan 4b). Hasil ini menunjukkan adanya aktivitas proliferasi yang berlebihan pada kelompok DMBA dibandingkan kelompok tanpa perlakuan. Adanya aktivitas proliferasi sel yang berlebih pada kelompok DMBA dimungkinkan terjadinya karsinogenesis pada hepar tikus.

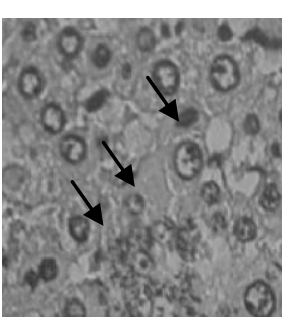

(a)

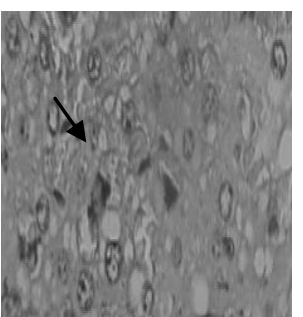

(b)

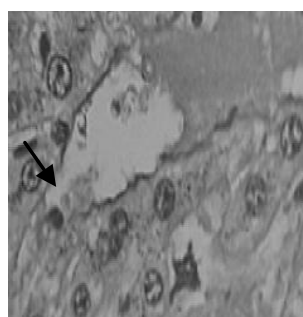

(c)

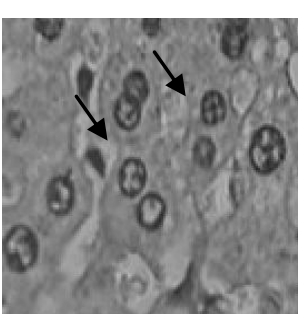

(d)

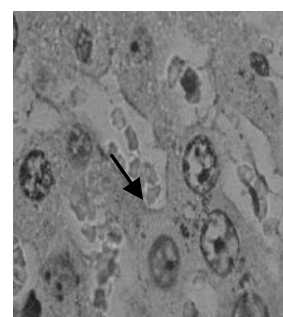

(e)

Gambar 1-Efek penghambatan proliferasi sel hepar tikus terinduksi DMBA oleh ekstrak etanolik kulit $C$. reticulata. Pengukuran proliferasi sel dilakukan dengan pewarnaan menggunakan perak nitrat. Aktivitas proliferasi ditunjukkan oleh jumlah black dot yang terdapat pada sel (ditunjukkan dengan tanda panah). Gambar di atas menunjukkan sel hepar tikus kelompok: DMBA (a), kontrol pelarut CMC-Na 0,5\% (b), kontrol ekstrak dosis $1500 \mathrm{mg} / \mathrm{kg} \mathrm{BB}$ (c), DMBA+ekstrak 750 $\mathrm{mg} / \mathrm{kgBB}$ (d) dan DMBA+ekstrak $1500 \mathrm{mg} / \mathrm{kgBB}$ (e) pada mikroskop cahaya dengan perbesaran 1000x. Preparat histologi jaringan diimersikan dalam buffer sodium sitrat $\left(\mathrm{pH} \mathrm{6,0)}\right.$ kemudian diinkubasi di dalam autoclave pada suhu $120^{\circ} \mathrm{C}$ (tekanan $1,1-1,2$ bar).

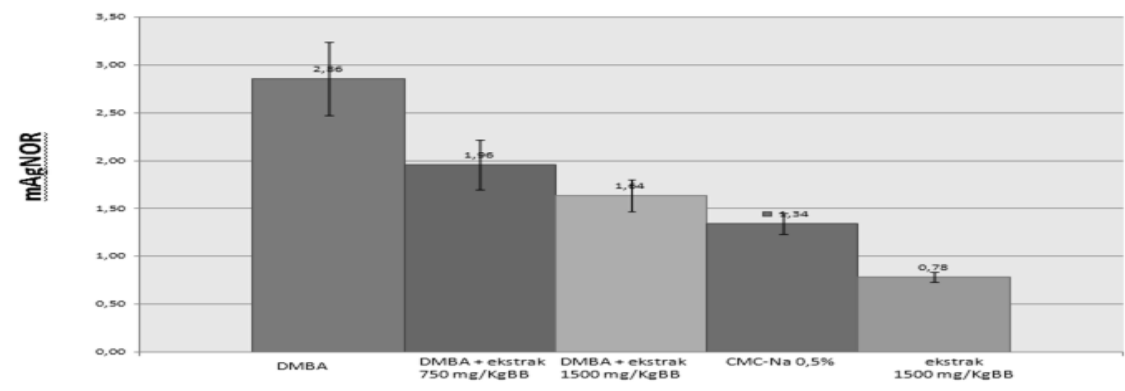

perlakuan

Gambar 2-Efek penurunan jumlah blackdot sel hepar tikus akibat pemberian ekstrak kulit jeruk keprok. Kuantifikasi black dot pada sel hepar yang menunjukkan penurunan persentase jumlah black dot karena pemberian ekstrak (purata blackdot \pm SD) diperoleh dengan menghitung 100 sel tiap lapang pandang dengan perbesaran 1000x, sebanyak 10 lapang pandang yang berbeda. Semua kelompok perlakuan menunjukkan perbedaan signifikan dengan kelompok DMBA dengan taraf signifikansi dengan $\mathrm{p}<0,05$. 
Jumlah black dot pada kelompok perlakuan DMBA+ekstrak (750 dan 1500 $\mathrm{mg} / \mathrm{kgBB}$ ) lebih sedikit dibandingkan jumlah black dot kelompok DMBA (Gambar 1a, 1d, dan 1e). Penurunan jumlah black dot menunjukkan bahwa ekstrak dapat menurunkan tingkat proliferasi sel hepar. Penurunan jumlah black dot bersifat tergantung dosis. Analisis statistik dengan menggunakan uji one-way ANOVA memberikan perbedaan skor mAgNOR secara signifikan antara kelompok DMBA dengan DMBA+ekstrak $1500 \mathrm{mg} / \mathrm{kgBB}$ (Gambar 2). DMBA+ekstrak 1500 tidak berbeda signifikan terhadap terhadap kontrol pelarut dan kontrol ekstrak $(P>0,05)$.

Peningkatan proliferasi sel dan terjadinya overekspresi onkogen merupakan alasan yang menjadikan penyakit kanker sangat mematikan. Pentingnya penekanan ekspresi onkogen dan penghambatan proliferasi sel pada penyakit kanker telah menjadi target pencegahan kanker (Kawajiri, 1993). Salah satu metode yang dapat digunakan untuk mendeteksi ekspresi onkogen adalah dengan Immunohistokimia.

\section{PEMBAHASAN}

Salah satu senyawa dalam kulit $C$. reticulata yang mempunyai efek kemopreventif adalah flavonoid. Mekanisme pencegahan kanker oleh senyawa flavonoid meliputi antiproliferasi, cell cycle arrest, dan penekanan ekspresi onkogen tertentu (Ren et al., 2003). Hal tersebut didukung dengan penelitian secara in vitro yang menunjukkan ekstrak kulit jeruk Keprok (C. reticulata) mempunyai efek antiproliferasi dan dapat menginduksi apoptosis pada sel kanker lambung SNU-668 (Kim et al., 2005). Dalam penelitian ini ekstrak etanolik kulit C. reticulata mempunyai kandungan flavonoid yang telah dibuktikan dengan pereaksi sitroborat.

Kandungan polimetoksi flavonoid tangeretin dan nobiletin dalam kulit jeruk keprok sangat tinggi. Tangeretin dilaporkan dapat menghambat invasi dan metastasis pada sel HL-60 (Bracke et al., 1994), selain itu nobiletin juga bersifat antiproliferatif pada sel kanker skuamosa (Kandawaswami et al., 1991). Tangeretin juga dapat menghambat pertumbuhan sel fase G1 pada sel kanker COLO 205 (Pan et al., 2002). Dalam penelitian ini pemberian ekstrak selama 7 hari menunjukkan hasil bahwa kandungan senyawa yang terdapat dalam ekstrak dapat menghambat proliferasi pada sel hepar terinduksi DMBA (Gambar 1d dan 1e). Wardani et al., 2008 juga meyebutkan bahwa ekstrak etanolik kulit $C$. reticulata mampu menekan ekspresi c-Myc pada hepar tikus terinduksi DMBA.

Salah satu mekanisme penurunan insidensi kanker pada sel hepar setelah pemberian ekstrak kemungkinan disebabkan oleh suatu senyawa aktif yang terkandung di dalam ekstrak. Senyawa di dalam ekstrak etanolik kulit jeruk $C$. reticulata yang diduga mempunyai efek tersebut adalah senyawa golongan flavonoid terutama golongan polimetoksiflavon (Walle, 2007). Terjadinya penurunan proliferasi dan penurunan ekspresi c-Myc dimungkinkan karena kandungan flavonoid tangeretin dan nobiletin. Hal tersebut merujuk pada penelitian Nugroho et al (2008) yang menyebutkan bahwa kedua senyawa tersebut mampu berinteraksi dengan ligan cSrc yang merupakan up stream dalam pembentukan c-Myc. Namun dalam penelitian ini keberadaan tangeretin dan nobiletin dalam ekstrak belum diketahui kadarnya. Oleh karena itu perlu dilakukan penelitian lebih lanjut mengenai hal tersebut.

Prospek ekstrak etanolik kulit $C$. reticulata dapat digunakan sebagai suppressing agent pada karsinogenesis karena dapat menghambat proliferasi dan mempunyai kemampuan menekan ekspresi onkogen c-Myc (Wardani et al., 2008). Penelitian ini menunjukkan bahwa ekstrak etanolik kulit $C$. reticulata mempunyai potensi kemopreventif yang besar dalam menghambat pertumbuhan kanker hepar. Hasil penelitian ini dapat dijadikan landasan menganai penggunaan kulit C. reticulata sebagai bahan kemopreventif dan dapat juga dipergunakan untuk pengembangan penelitian-penelitian selanjutnya mengenai terapi kanker hepar.

\section{KESIMPULAN}

Hasil penelitian menunjukkan bahwa pemberian ekstrak etanolik kulit jeruk keprok dapat menekan karsinogenesis melalui penghambatan proliferasi dan penekanan ekspresi c-Myc pada sel hepar tikus terinduksi DMBA, sehingga kulit jeruk keprok dapat dijadikan bahan kemopreventif.

\section{UCAPAN TERIMAKASIH}

DP2M DIKTI yang telah membantu mendanai penelitian ini melalui program PKM 2008

\section{DAFTAR PUSTAKA}

Bracke, M., Bruyneel, E.A., Vermeulen, S.J., Vennekens, K., Marck,V.V. and Mareel, M.M. 1994. 'Citrus flavonoid effect on tumor invasion and metastasis', Food Technol, vol. 48, pp. 121-142 
Derenzini, M., Trere, D., O'Donohue, M. F.and, Ploton, D. 2003. Interphase Nucleolar Organiser Regions in Tumour Pathology. Crocker, J and Murray, P.G (editor), Molecular Biology in Cellular Pathology. John Wiley \& Sons Ltd, Chichester

Wardani, D.A.P.K., Nugroho, P.A., Darma, A.P., Ikawati, M., Riyanto, S., and Meiyanto., 2008, Potensi Kemopreventif Ekstrak Etanolik Kulit Jeruk Keprok (Citrus reticulata) pada Sel Kanker Hepar Tikus Galur Sprague Dawley Terinduksi 7,12-dimetilbenz[a]antrasena Melalui Penekanan Ekspresi c-Myc, Prosiding Kongres IImiah ISFI XVI 2008, ISBN: 978-979-95107, Ikatan Sarjana Farmasi Indonesia

Izzotti, Alberto, Camoirano, Anna, Cartgilia, C., Grubbs, and Clinton J. 1999. 'Patterns of DNA Adduct Formation in Liver and Mammary Epithelial Cells of Rats Treated with 7,12Dimethylbenz[a]anthracene, and Selective Effects of Chemopreventive Agents', J.Can. Res, vol. 59, pp. $4285-4290$

Kandawaswami, C., Perkins, E., Soloniuk, D.S., Drzewiecki, G. and Middleton, E.,Jr. 1991. Antiproliferative effects of citrus flavonoids on a human squamous cell carcinoma in vitro, Cancer Lett, vol. 56, pp. 147-152

Kawajiri, K., Nakachi, K., Imai, K., Watanabe, J and Hayashi, S (1993) The CYP1A1 gene and cancer susceptibility. Crit Rev Oncol Hematol 14:77-87

Kim, M.J., Park, H.J., Hong, M.S., Park, H.J., Kim, M.S., and Leem, K.H., 2005. Citrus Reticulata Blanco Induces Apoptosis in Human Gastric Cancer Cells SNU-668, Nutrition and Cancer, vol. 51, no.1, pp. 78-82

La Rosa, F.A., 1994, Differential Regulation of the c-Myc Oncogene Promotor by the NF-kB Rel Family of Transcription Factor, Molecular and Cellular Biology,1039-1044

Moriguchi, T., Kitai, M., Hasegawa, S., and Omur, M. 2003. 'Molecular approach to citrus flavonoid and limonoid biosynthesis', Food, Agriculture \& Environment, vol. 1, no. 1, pp. 22-25

Nogata, Y., Sakamoto, K., Shiratsuci, H., Ishii, T., Yano, M and Ohta, H. 2006. 'Flavonoid Composition of Fruit Tissues of Citrus Species', Biosci.Biotechnol.Biochem, vol. 70, no.1, pp. 178192

Pan, M. H., Chen, W. J., Shiau, S. Y. L., Ho, C. T., and Lin, J. K. 2002. Tangeretin Induced Cell Cycle G1 Arrest through Inhibiting Cyclin Dependent Kinases 2 and 4 Activities as well as Elevating Cdk Inhibitor p21 and p27 in Human Colorectal Carcinoma Cell, Carcinogenesis, vol. 23, no. 10, pp. 1677-1684

Nugroho, P.A.., Wardani, D.A.P.K, Darma, A.P., Riyanto, S., and Meiyanto, E., 2008., Penelusuran Mekanisme Penekanan Ekspresi N-RAS Ekstrak Etanolik Kulit Jeruk Keprok (C. reticulata) Sebagai Agen Kemopreventif Melalui Docking Molekuler Pada Protein Target C-Src dan CYP1A2, Prosiding Kongres IImiah ISFI XVI 2008, ISBN : 978-979-95107, Ikatan Sarjana Farmasi Indonesia

Ren, W., Zhenhua, Q., Hongwei, W., Lei, Z., and Li, Z. 2003. Flavonoids: Promising Anticancer Agents, Medicinal Research Reviews, vol. 23, no. 4, pp.519-534

Walle, T., 2007, Methoxylated flavones, a superior cancer chemopreventive flavonoid subclass?,Seminars in Cancer Biology, vol. 17, 354-362

Zhai, S., Dai, R., Friedman, F. K., and Vestal, R. E., 1998, Comparative inhibition of human Cytochromes P4501A1 and 1A2 by flavonoids, The American Society for Pharmacology and Experimental Therapeutics vol. 26, no. 10, 989-992 